\title{
Pupils' Motivation and Attitudes Towards the Use of English Songs in Rural Primary English Classroom
}

\author{
Joyce Joel, Parilah Mohd Shah
}

\begin{abstract}
English teachers teaching in rural areas often face the non-availability of required technical support and relevant atmosphere to teach English effectively. As a result of the incompetent conditions, many studies have been conducted to exploit the unique components of songs to motivate the rural learners to learn English. However, a study to investigate the rural pupils in Kanowit, Sarawak toward the use of songs has not been located. Therefore, this study investigates Kanowit primary school pupils' attitudes towards English and investigate whether songs help to motivate rural pupils in Kanowit to learn English. A total 60 respondents, age between 10-12 years old took part in this preliminary study. Data was collected via a questionnaire survey . A survey questionnaire adapted from Gardner's (1985) Attitude and Motivation Test Battery (AMTB) was employed in this study. The findings suggest that students are highly motivated, have positive attitudes towards learning English and are extrinsically motivated although it does not necessarily translate into favorable efforts in improving proficiency. Based on the findings some suggestions and recommendations for teachers have been highlighted.
\end{abstract}

Index Terms - attitudes, motivation, rural Kanowit, rural learners, using songs

\section{INTRODUCTION}

English was a language spoken and written globally. It was used by billion of people internationally. Language learning was not easy especially for the second language learners. English plays a significant part in Malaysian Education system, where it is viewed as a second language as well as a language of knowledge, which can help Malaysians gain better employment and thus gain better social status. Malaysia consisted of different ethnics especially in Borneo which included Sabah and Sarawak. As English plays a significant part in Malaysian Education system, the fact that the proficiency of students in rural areas is not up to par is undeniably disturbing [1]. If compared with pupils in urban area, pupils in rural area were not aware of the importance of English language. There was a wide gap between rural and urban pupils' English proficiency. The concern over low achievement of English language among rural Malaysia learners, especially in rural areas in Sarawak has been investigated broadly for a very long period.

According to Thang et al., [2] attitudes and motivation of pupils towards learning English is said to be among the factors to low proficiency and passing rates in schools. Pupils pessimistic prior experiences with English instruction in a classroom environment further turn down their motivation to learn English. In view of this, it was essential for teachers to take their teaching styles or even teaching materials seriously.

Chandler [3] suggests that using songs in English learning classroom would be helpful either solely as a morale booster or by giving the pupils enough exposure to the language used. The melody of a song can help the students to remember the structures and words and the songs can therefore represent a great support to other teaching methods. According to Yunus et al [4], motivation is the most intermittent and essential concerns to a successful learning. Teacher should know their pupils' abilities and find the most suitable methods in helping them in the long and difficult way of the acquisition of a second language. Therefore, it was suitable to integrate English songs in the language classroom. Reflected upon the problem addressed above, the researcher selected the integration of English songs in rural English classroom after considered the setting of the research and pupils' background. The used of English songs promoted the development of language skills and created suitable learning atmosphere to inculcate positive attitudes among rural pupils in Kanowit districts toward learning English.

English songs in rural classroom in primary school of Kanowit districts of Sarawak. According to Gobel et al [5], rural pupils are in an environment where English is a foreign language. In other words, rural pupils merely used English language during English lesson and when they went back home, there was no English environment. Besides, rural pupils had limited time and chance to use the language in their daily conversations. Consequently, the rural pupils generally lack of attention and lost their interest to learn English.

The following research questions had been formulated based on the pupils' motivation and attitudes towards the used of English songs in the rural classroom at a particular rural primary school in Kanowit, Sarawak;

a) What is the overall attitude of the weak and intermediate pupils toward the use of English songs in rural English learning classroom at a particular rural primary school in Kanowit, Sarawak?

b) Does English songs help to motivate the rural pupils in Kanowit, Sarawak to learn English? 


\section{LITERATURE REVIEW}

\section{A. Attitude and Motivation}

Attitudes and motivation have a very clear link with the language learning process. According to Latchanna and Dagnew [6], motivation, attitudes and beliefs about learning a language are among the determining factors that influence a student's efficiency and must be taken into account when understanding second language learning processes. Without any motivation or positive attitude, there can hardly be a successful process of learning. Lennartsson [7] stated that students' beliefs can be an obstacle if they believe that they cannot learn the new language successfully. Motivated students have positive attitudes towards learning English. Attitudes and motivation contribute to the success of language learning.

\section{B. Positive Impact of Using Songs in the Classroom}

Teachers may adopt songs in the ESL classroom for many reasons and they mainly come from three different aspects: affective, cognitive and linguistic [8]. In ESL teaching and learning, songs have been acknowledged by numerous researchers and teachers as highly potential tool to promote language acquisition.

Brewster, Ellis and Girard [9] mention songs help to develop concentration, memory and coordination. By nature, children love to play, sing and have fun. Young ESL students are happy to listen to and sing along with a song since it is fun and catchy. Songs can help to boost their motivation and attention, resulting to a more lively and student-centred learning. Songs allow students to concentrate on lessons and become active learners.

Schmitt [10] identifies that one of the best principles for students in learning a foreign language is to be motivated to do things that are interesting, relevant to their goals and enjoyable. Hence, using songs in ESL classroom could create such opportunities. Songs too, have been argued to reduce tense in classroom.

Schoepp [8] pointed out that using songs is one useful method to achieve a weak affective filter and promotes language learning, based on Krashen's Affective Filter Hypothesis. This means language students need to have positive attitudes towards learning and using songs is one way to achieve it. Realizing the power of integrating and exploiting songs into the teaching and learning of ESL, Malaysian government has recently designed a new English language curricular for primary school that emphasizes on the use of songs. The English textbooks have a number of songs included and are encouraged to be used during the teaching and learning process.

Using songs in rural classroom can be a valuable tool because of its nature of flexibility. Songs can be a flexible tool to serve a number of learning purposes such as to improve learners' listening skills and pronunciation. For this reason, using song as a pedagogical tool has the potential to help improve the learners' speaking skills. In conclusion, the used of English songs in the classroom brought a positive impact on individual's learning, which allow pupils to be more motivated as the pupils able to work on authentic activities.

\section{Songs as Pedagogical Tools}

According to Brewster [9], there are many advantages of using songs as a learning resource. First, songs act as a linguistic resource. At this point, songs become a medium of introduction to a new language, hence become a useful resource to improve vocabulary and grammar. In addition, songs interpret language in a more comfortable and fun way for the learners as the element of repetition that exists in a song enables the learning to be more effective. The usage of songs in teaching should be utilize to the maximum level as it is able to integrate all language skills interactively, so as to improve the pronunciation of the learners. Second, songs have been an effective psychological resource. Apart from its calming element, songs also able to motivate the learners and instill positive attitude. Third, songs also operate as a cognitive resource. Songs help improve learners' memory, concentration and coordination. Songs help learners to punctuate their words better as to create more meaningful words. As concluded by Brewster [9], songs create a significant impact to the learning of pronunciation. Learners able to practice their pronunciation in a natural way when using songs in learning the language. Songs are indeed an invaluable resources used to develop pupils' abilities in all the four language skills. Teacher can drill their pupils on both of these processes using songs as it is important for developing the pupils' listening comprehension. As cited in Nadera [11], songs can be useful tools in learning new vocabulary, sentence structures and patterns, and promote reflection on their mother tongue culture.

\section{METHODOLOGY}

\section{A. Research Design}

This paper is a preliminary study to investigate the effects of songs on pupils motivation and attitudes towards English and the relationship between the use of songs (independent variable) and pupil engagement (independent variable). Hence, this quantitative research employed a survey research design.

\section{B. Participants and Setting}

Sixty pupils $(n=60)$ from rural primary schools in Kanowit, Sarawak participated in this survey. The respondents chosen were from the upper primary level. They were 32 Iban girls and 28 Iban boys aged between 10 to 12 years old took part in this study. The only exposure that the participants receive is at school, during the English language subject. They come from a family of mostly farmers. Some of them live with their grandparents in the longhouse and their parents are working at the nearby town. They stayed in the boarding school and only go home on Friday after class. The selected participants were chosen from a random sampling process and they had just received their End of Year examination results, where they were considered "intermediate" to "weak" pupils based on their results. 30 out 60 pupils were categorized under intermediate group of pupils since they attained $\mathrm{B}$ and $\mathrm{C}$ grades in their recent English examination. 30 out 60 pupils were categorized under weak group that attained D and E grades in their English examination.

The questionnaire was administered after the pupils were briefed on the purpose of the research and the scale 
used. Participants were required to answer all the items honestly.

Noted that the demography factors of the pupils were not being tested in this study although being included in the questionnaires.

\section{Instruments}

A survey questionnaire adapted from Gardner's (1985) Attitude and Motivation Test Battery (AMTB) was employed in this study. The questionnaire was translated into Bahasa Malaysia since the respondents were considered weak based on their End of Year Examination result. The questionnaire contained 23 items and was divided into three sections. The first part consisted of three items which seek information on pupils' background. The second part contained ten items to draw out information regarding their attitudes towards learning English and the third section contained ten items aimed at extracting pupils' level of motivation. The questionnaire was designed using 5 Likert scale where 5 indicated respondents strongly agreed with the statement, 4 agree, 3 neutral, 2 disagree and 1 strongly disagree.

The questionnaire had been sent to a TESL lecturer for validity and it was proven valid to be used in this study.

\section{Procedures}

These procedures were followed when collecting data from the participants. First and foremost, permission was obtained from the headmaster of the school. Then, questionnaires were distributed to the participants in the particular school during their last lesson break in October where English song was being used as a pedagogical tool for 3 months, since August 2017 until October 2017. Instructions on the questionnaires were given orally before it was administered. The written instructions were also given in the questionnaires. The respondents were instructed to answer the questionnaires in 30 minutes; so that the teaching and learning process were not being disturbed.

The data collected from the respondents was analyzed using SPSS program (Statistical Package for the Social Science) version 22 for further statistical analysis. Descriptive statistics such as frequency and percentage were being used. The results of the questionnaires were presented in tables with elaborations.

\section{DATA ANALYSIS}

The results from the survey were analyzed using SPSS program (Statistical Package for the Social Science) version 22 that involved descriptive statistics which include frequencies and percentages. Pseudonyms were used to retain anonymity and participants' confidentiality. The following was the presentation of data analysis of Kanowit students' motivation and attitudes towards the use of English songs in rural primary English classroom.
Comparison between the weak pupils and intermediate pupils' attitude toward the use of English songs in the teaching and learning of English

TABLE I. PERCENTAGE AND FREQUENCY OF THE PUPILS' INTRINSIC ATTITUDE ON THE USE OF SONGS IN ENGLISH LESSON

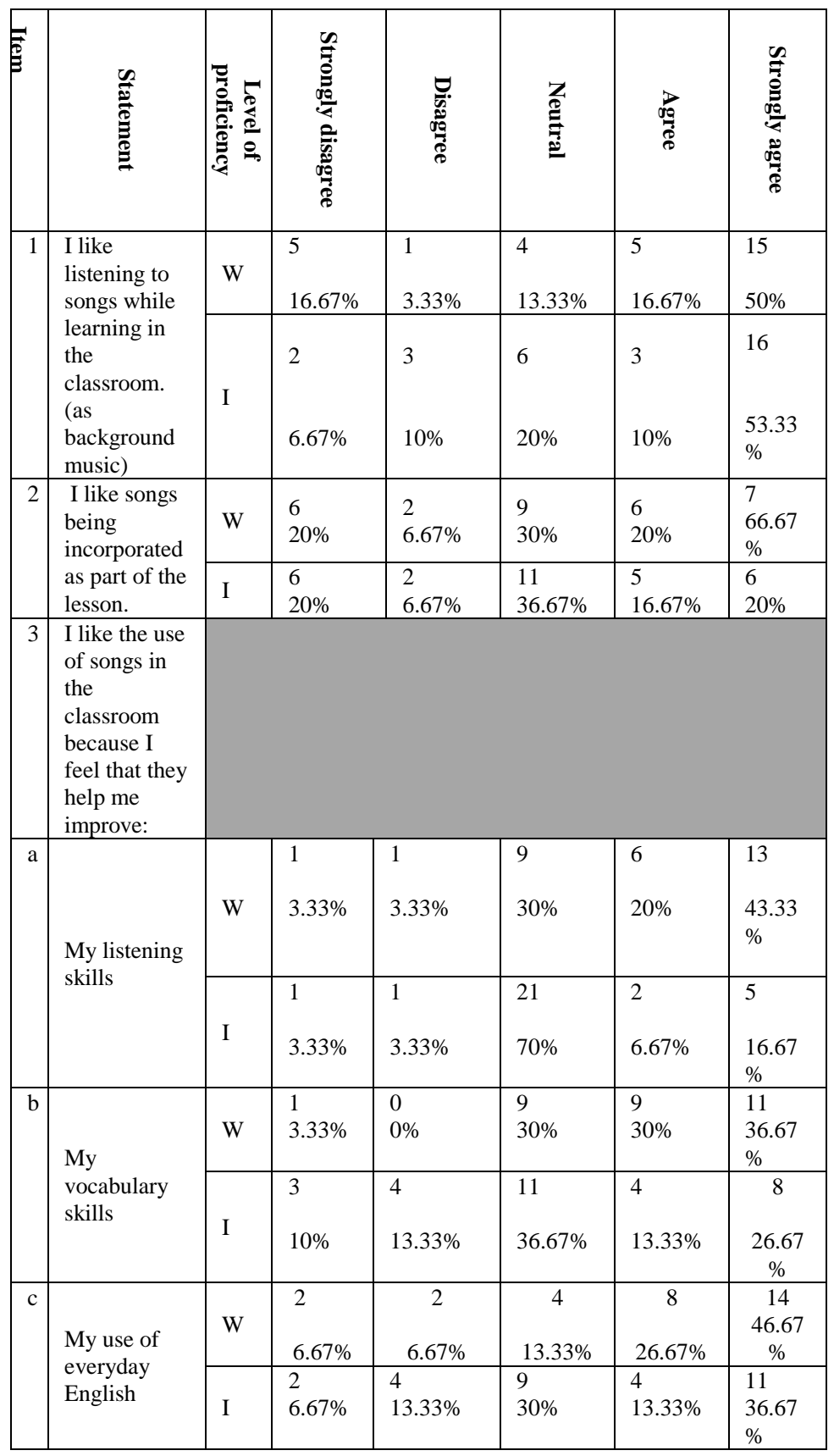

As can be observed in Table 1, both weak pupils, 50\% $(n=15)$ and intermediate pupils, $53.33 \%(n=16)$ were strongly agreed with listening to songs while learning in the classroom. However, as for Item 2, both weak pupils, 30\% $(n=9)$ and intermediate pupils, 36.67\% $(n=11)$ were neutral when English songs were incorporated as part of the lesson. Pupils were neither agreed nor disagreed with the statement. On the other hand, for Item 3 , weak pupils strongly agree with all the 3 sub-items. To be exact, $43.33 \%(n=13)$ pupils were strongly agreed with the statement the used of songs in the classroom helped to improved them in listening skills, 
$36.67 \%(\mathrm{n}=11)$ in vocabulary skills and $46.67 \%(14)$ in everyday used of English.

In contrast with weak pupils, intermediate pupils had different opinions. $70 \%(n=21)$ pupils were neutral with the statement the used of songs in the classroom helped to improved them in listening skills and $36.67 \%(\mathrm{n}=11)$ in vocabulary skills. Meanwhile, $36.67 \%(\mathrm{n}=11)$ pupils strongly agreed with the use of English songs in everyday used of English.

TABLE II. PERCENTAGE AND FREQUENCY OF THE PUPILS' INTRINSIC ATTITUDE ON THE IMPACT OF SONGS IN ENGLISH LESSON

\begin{tabular}{|c|c|c|c|c|c|c|c|}
\hline $\overrightarrow{\underline{\underline{Q}}}$ & 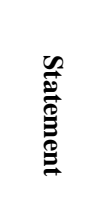 & 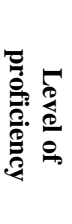 & 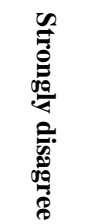 & 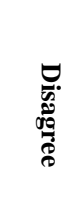 & 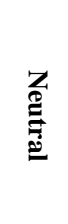 & $\frac{8}{80}$ & 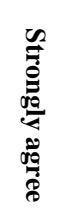 \\
\hline \multirow{2}{*}{4} & \multirow{2}{*}{$\begin{array}{l}\text { Using } \\
\text { songs in } \\
\text { the } \\
\text { classroo } \\
\mathrm{m} \\
\text { makes } \\
\text { the } \\
\text { experie } \\
\text { nce of } \\
\text { learning } \\
\text { English } \\
\text { more } \\
\text { enjoyab } \\
\text { le. }\end{array}$} & W & $0 \%$ & $\begin{array}{l}13.33 \\
\%\end{array}$ & $\begin{array}{l}13.3 \\
3 \%\end{array}$ & $20 \%$ & $\begin{array}{l}53.3 \\
3 \%\end{array}$ \\
\hline & & I & $3.33 \%$ & $\begin{array}{l}13.33 \\
\%\end{array}$ & $20 \%$ & $16.67 \%$ & $\begin{array}{l}46.6 \\
7 \%\end{array}$ \\
\hline \multirow[t]{2}{*}{5} & \multirow{2}{*}{$\begin{array}{l}\text { I don't } \\
\text { mind } \\
\text { what } \\
\text { type of } \\
\text { music } \\
\text { the } \\
\text { teacher } \\
\text { plays in } \\
\text { the } \\
\text { classroo } \\
\text { m. }\end{array}$} & W & $6.67 \%$ & $\begin{array}{l}16.67 \\
\%\end{array}$ & $\begin{array}{l}33.3 \\
3 \%\end{array}$ & $13.33 \%$ & $30 \%$ \\
\hline & & I & $\begin{array}{l}8 \\
26.67 \\
\%\end{array}$ & $\begin{array}{l}5 \\
16.67 \\
\%\end{array}$ & $\begin{array}{l}4 \\
13.3 \\
3 \%\end{array}$ & $\begin{array}{l}5 \\
16.67 \%\end{array}$ & $\begin{array}{l}8 \\
26.6 \\
7 \%\end{array}$ \\
\hline
\end{tabular}

The findings shown in Table 2 displayed the percentage and frequency of the pupils' intrinsic attitude on the impact of songs in English lesson. Both weak pupils, 53.33\% $(n=16)$ and intermediate pupils, $46.67 \%(\mathrm{n}=14)$ were strongly agreed with Item 4 which stated that the used of songs in the classroom makes the experience of learning English more enjoyable. On the other hand, pupils' opinions to Item 5 were varied. Weak pupils, $33.33 \%(n=10)$ were neutral with the statement while an equal number of intermediate pupils, $3.33 \%(n=8)$ were strongly agreed and strongly disagreed with the types of music played.
TABLE III. PERCENTAGE AND FREQUENCY OF THE PUPILS' INTRINSIC ATTITUDE ON THE EFFECTIVENESS OF SONGS IN ENGLISH LESSON

\begin{tabular}{|c|c|c|c|c|c|c|c|}
\hline $\overrightarrow{\widehat{\Theta}}$ & 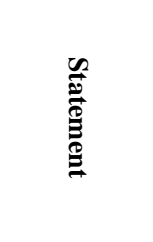 & 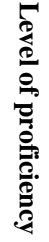 & 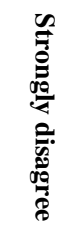 & 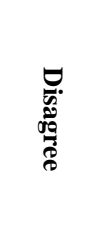 & 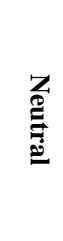 & $\underset{8}{\stackrel{8}{8}}$ & 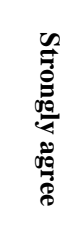 \\
\hline \multirow[b]{2}{*}{6} & \multirow{2}{*}{$\begin{array}{l}\text { The use of } \\
\text { songs in the } \\
\text { classroom } \\
\text { has resulted } \\
\text { in me } \\
\text { singing } \\
\text { along to } \\
\text { English } \\
\text { songs more } \\
\text { (accurately). }\end{array}$} & $\mathrm{W}$ & $\begin{array}{l}3 \\
10 \%\end{array}$ & $\begin{array}{l}2 \\
6.67 \%\end{array}$ & $\begin{array}{l}7 \\
23.3 \\
3 \% \\
\end{array}$ & $\begin{array}{l}7 \\
23.3 \\
3 \% \\
\end{array}$ & $\begin{array}{l}11 \\
36.67 \\
\% \\
\end{array}$ \\
\hline & & I & $10 \%$ & $13.33 \%$ & $\begin{array}{l}26.6 \\
7 \%\end{array}$ & $\begin{array}{l}3.33 \\
\%\end{array}$ & $\begin{array}{l}46.67 \\
\%\end{array}$ \\
\hline \multirow[b]{2}{*}{7} & \multirow{2}{*}{$\begin{array}{l}\text { I have used } \\
\text { new words } \\
\text { and phrases, } \\
\text { since I have } \\
\text { learnt from } \\
\text { songs, } \\
\text { outside of } \\
\text { the } \\
\text { classroom. }\end{array}$} & W & $\begin{array}{l}4 \\
13.33 \\
\% \\
\end{array}$ & $\begin{array}{l}0 \\
0 \%\end{array}$ & $\begin{array}{l}11 \\
36.6 \\
7 \% \\
\end{array}$ & $\begin{array}{l}2 \\
6.67 \\
\%\end{array}$ & $\begin{array}{l}13 \\
43.33 \\
\%\end{array}$ \\
\hline & & I & $6.67 \%$ & $13.33 \%$ & $\begin{array}{l}36.6 \\
7 \%\end{array}$ & $10 \%$ & $\begin{array}{l}33.33 \\
\%\end{array}$ \\
\hline
\end{tabular}

According to Table 3, both weak pupils, 36.67\% ( $\mathrm{n}=11)$ and intermediate pupils, $46.67 \%(\mathrm{n}=14)$ were strongly agreed with the statement in Item 6 . Yet, as for Item 7, weak pupils, $43.33 \%$ (13) were strongly agreed while intermediate pupils, $36.67 \%(n=11)$ were neutral with the statement. 
TABLE IV. PERCENTAGE AND FREQUENCY OF THE PUPILS' INTRINSIC ATTITUDE ON HOW THE USE OF SONGS IN ENGLISH LESSON PROMOTE ACTIVE PARTICIPATION

\begin{tabular}{|c|c|c|c|c|c|c|c|}
\hline $\overrightarrow{\underline{\Xi}}$ & 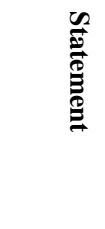 & 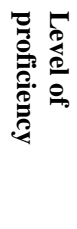 & 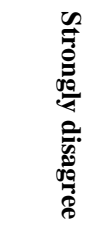 & 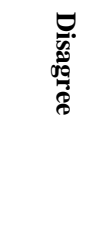 & 父 & $\frac{8}{80}$ & 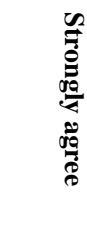 \\
\hline \multirow[b]{2}{*}{8} & \multirow{2}{*}{$\begin{array}{l}\text { Help } \\
\text { shy } \\
\text { learner } \\
\text { s like } \\
\text { me to } \\
\text { particip } \\
\text { ate in } \\
\text { the } \\
\text { activity } \\
\text {. }\end{array}$} & W & $\begin{array}{l}4 \\
13.33 \\
\%\end{array}$ & $\begin{array}{l}1 \\
3.33 \%\end{array}$ & $\begin{array}{l}9 \\
30 \%\end{array}$ & $\begin{array}{c}8 \\
26.67 \\
\%\end{array}$ & $\begin{array}{c}8 \\
26.67 \\
\%\end{array}$ \\
\hline & & I & $20 \%$ & $6.67 \%$ & $\begin{array}{l}33.33 \\
\%\end{array}$ & $\begin{array}{l}16.67 \\
\%\end{array}$ & $\begin{array}{l}23.33 \\
\%\end{array}$ \\
\hline \multirow[b]{2}{*}{9} & \multirow{2}{*}{$\begin{array}{l}\text { Help } \\
\text { me to } \\
\text { be } \\
\text { more } \\
\text { confide } \\
\text { nt in } \\
\text { using } \\
\text { English } \\
\text {. }\end{array}$} & W & $\begin{array}{l}1 \\
3.33 \%\end{array}$ & $\begin{array}{l}1 \\
3.33 \%\end{array}$ & $\begin{array}{l}9 \\
30 \%\end{array}$ & $\begin{array}{l}6 \\
20 \%\end{array}$ & $\begin{array}{l}13 \\
43.33 \\
\%\end{array}$ \\
\hline & & I & $3.33 \%$ & $20 \%$ & $\begin{array}{l}36.67 \\
\%\end{array}$ & $\begin{array}{l}13.33 \\
\%\end{array}$ & $\begin{array}{c}26.67 \\
\%\end{array}$ \\
\hline \multirow{2}{*}{10} & \multirow{2}{*}{$\begin{array}{l}\text { Promot } \\
\text { e whole } \\
\text { class } \\
\text { particip } \\
\text { ation. }\end{array}$} & W & $\begin{array}{l}3 \\
10 \%\end{array}$ & $\begin{array}{l}1 \\
3.33 \%\end{array}$ & $\begin{array}{l}5 \\
16.67 \\
\%\end{array}$ & $\begin{array}{l}5 \\
16.67 \\
\%\end{array}$ & $\begin{array}{l}16 \\
53.33 \\
\%\end{array}$ \\
\hline & & I & $\begin{array}{l}1 \\
3.33 \%\end{array}$ & $\begin{array}{l}1 \\
3.33 \%\end{array}$ & $\begin{array}{l}7 \\
23.33 \\
\%\end{array}$ & $\begin{array}{l}1 \\
3.33 \%\end{array}$ & $\begin{array}{l}20 \\
66.67 \\
\%\end{array}$ \\
\hline
\end{tabular}

The findings displayed in Table 4 on the pupils' intrinsic attitude on how the use of songs in English lesson promote active participation. Both weak pupils, 30\% ( $\mathrm{n}=9)$ and intermediate pupils, $33.33 \%(\mathrm{n}=10)$ were neutral with Item 8.

Contrarily, $43.33 \% \quad(n=13)$ of the weak pupils were strongly agreed while $36.67 \%(n=11)$ of the intermediate pupils were neutral with Item 9. Both weak pupils, 53.33\%, $(\mathrm{n}=16)$ and intermediate pupils, $66.67 \%(\mathrm{n}=20)$ were strongly agreed with Item 10.
Comparison between the weak pupils and intermediate pupils' motivation on the use of English songs in the teaching and learning of English

TABLE V. PERCENTAGE AND FREQUENCY OF THE WEAK AND INTERMEDIATE PUPILS' MOTIVATION ON THE USE OF EONGS IN ENGLISH LESSON

\begin{tabular}{|l|l|l|l|l|l|l|l|}
\hline & & & & & & \\
&
\end{tabular}

The result in Table 5 displayed the pupil's motivation on the use of songs in English lesson. Weak pupils, $46.67 \%$ $(n=14)$ were strongly agreed with Item 1 , while intermediate pupils, $36.67 \%(n=11)$ were neutral. Intermediate pupils were just neither agree nor not agree with the statement. As for Item 2, weak pupils, 33.33\% ( $\mathrm{n}=10)$ were agreed whilst intermediate pupils, $43.33 \%(\mathrm{n}=13)$ were strongly agreed with the statement. Both weak pupils, 46.67\%, $(n=14)$ and intermediate pupils $43.33 \%(n=13)$ were strongly agreed with Item 3. 
TABLE VI. PERCENTAGE AND FREQUENCY OF THE WEAK AND INTERMEDIATE PUPILS' MOTIVATION ON THE USE OF EONGS IN ENGLISH LESSON FOR IMPROVEMENT

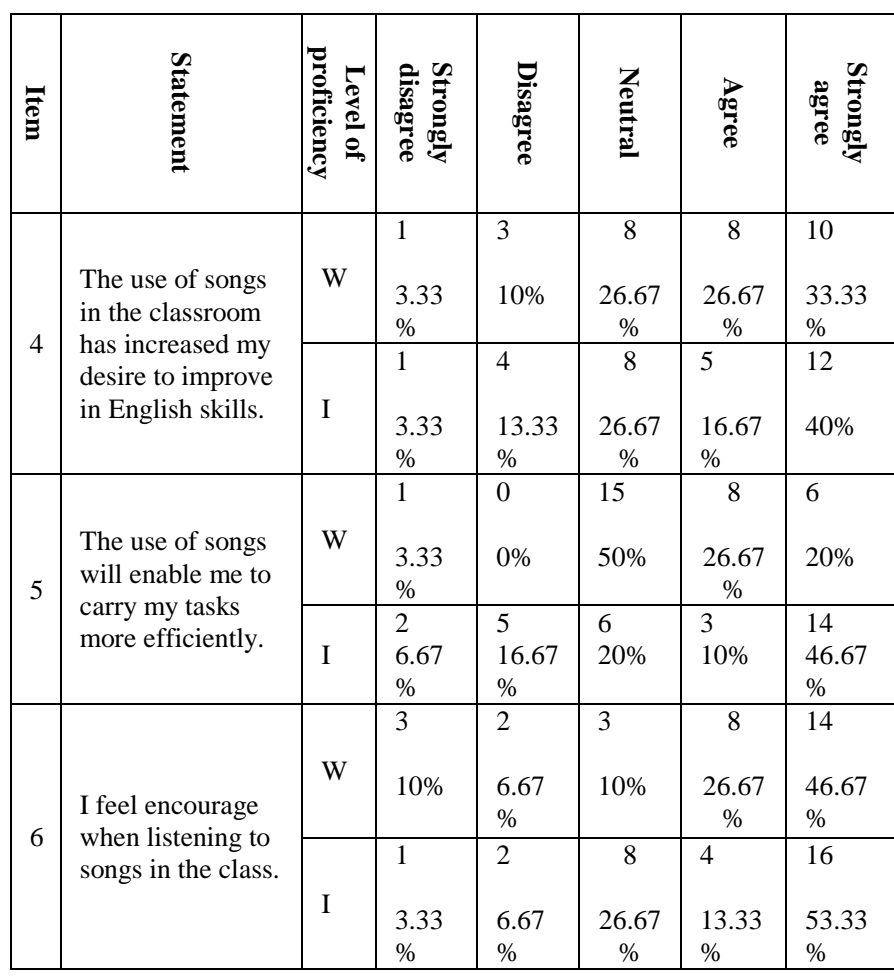

The result in Table 6 showed the pupil's intrinsic motivation on the use of songs in English lesson for improvement. Both weak pupils, 33.33\% $(\mathrm{n}=10)$ and intermediate pupils, $40 \%(\mathrm{n}=12)$ were strongly agreed with Item 4. For Item 5, both weak and intermediate pupils had different level of agreement to the statement. Majority of the weak pupils, $50 \%(n=15)$ were neutral while intermediate pupils, $46.67 \%(n=14)$ were strongly agreed with the statement.
TABLE VII. PERCENTAGE AND FREQUENCY OF THE WEAK AND INTERMEDIATE PUPILS' EXTRINSIC MOTIVATION ON THE USE OF EONGS IN ENGLISH LESSON FOR IMPROVEMENT

\begin{tabular}{|c|c|c|c|c|c|c|c|}
\hline $\overrightarrow{\overrightarrow{9}}$ & 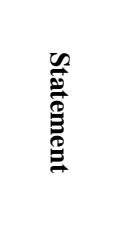 & 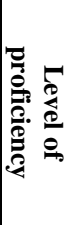 & 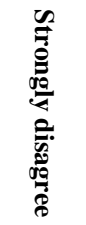 & 룽. & 誨 & $\underset{8}{\stackrel{8}{8}}$ & 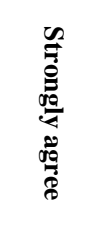 \\
\hline \multirow{2}{*}{7} & \multirow{2}{*}{$\begin{array}{l}\text { I feel } \\
\text { boring } \\
\text { when } \\
\text { there is } \\
\text { no music } \\
\text { in } \\
\text { English }\end{array}$} & W & $\begin{array}{l}1 \\
3.33 \%\end{array}$ & $\begin{array}{l}2 \\
6.67 \%\end{array}$ & $\begin{array}{l}6 \\
20 \%\end{array}$ & $\begin{array}{l}6 \\
20 \%\end{array}$ & $\begin{array}{l}15 \\
50 \%\end{array}$ \\
\hline & & I & $\begin{array}{l}8 \\
26.67 \\
\%\end{array}$ & $\begin{array}{l}1 \\
3.33 \%\end{array}$ & $\begin{array}{l}12 \\
40 \%\end{array}$ & $\begin{array}{l}4 \\
13.33 \%\end{array}$ & $\begin{array}{l}5 \\
16.67 \%\end{array}$ \\
\hline \multirow[t]{2}{*}{8} & \multirow{2}{*}{$\begin{array}{l}\text { The use } \\
\text { of songs } \\
\text { excite } \\
\text { me to } \\
\text { learn } \\
\text { English. }\end{array}$} & W & $6.67 \%$ & $0 \%$ & $16.67 \%$ & $30 \%$ & $46.67 \%$ \\
\hline & & I & $\begin{array}{l}0 \\
0 \%\end{array}$ & $\begin{array}{l}3 \\
10 \%\end{array}$ & $\begin{array}{l}9 \\
30 \%\end{array}$ & $\begin{array}{l}2 \\
6.67 \%\end{array}$ & $\begin{array}{l}16 \\
53.33 \%\end{array}$ \\
\hline \multirow{2}{*}{9} & \multirow{2}{*}{$\begin{array}{l}\text { The use } \\
\text { of songs } \\
\text { make me } \\
\text { feel } \\
\text { relax and } \\
\text { it helps } \\
\text { me to } \\
\text { learn in a } \\
\text { more } \\
\text { effective } \\
\text { way. }\end{array}$} & W & $3.33 \%$ & $3.33 \%$ & $26.67 \%$ & $23.33 \%$ & $43.33 \%$ \\
\hline & & I & $6.67 \%$ & $10 \%$ & $23.33 \%$ & $16.67 \%$ & $43.33 \%$ \\
\hline \multirow[t]{2}{*}{10} & \multirow{2}{*}{$\begin{array}{l}\text { Having } \\
\text { to learn } \\
\text { in } \\
\text { English } \\
\text { through } \\
\text { songs } \\
\text { made me } \\
\text { feel less } \\
\text { stress. }\end{array}$} & W & $10 \%$ & $3.33 \%$ & $20 \%$ & $16.67 \%$ & $50 \%$ \\
\hline & & I & $\begin{array}{l}6 \\
20 \%\end{array}$ & $\begin{array}{l}1 \\
3.33 \%\end{array}$ & $\begin{array}{l}5 \\
16.67 \%\end{array}$ & $\begin{array}{l}4 \\
13.33 \%\end{array}$ & $\begin{array}{l}14 \\
46.67 \%\end{array}$ \\
\hline
\end{tabular}

Table 7 displayed a result of pupils' extrinsic motivation on the use of songs in English lesson. As could be seen, majority of the pupils strongly agreed with the statements. For item 7 , weak pupils, 50\% $(n=15)$ were strongly agreed as intermediate pupils, $40 \%(\mathrm{n}=12)$ were neutral with the statement. Both weak pupils, 46.67\% $(n=14)$ and intermediate pupils, $53.33 \%(n=16)$ were strongly agreed with Item 8 . Equally, both weak and intermediate pupils obtained the same result from Item 9, that was $43.33 \%$ $(\mathrm{n}=13)$ for each level of pupils. Pupils were strongly agreed with Item 10 as for weak pupils, $50 \%(n=15)$ and intermediate pupils, $46.67 \%(n=14)$. 


\section{DISCUSSION AND CONCLUSION}

The results indicate that generally, the rural pupils had a positive attitudes towards the used of English songs in teaching and learning of English. This was based on the results and discussions presented. The major findings showed that majority of the pupils strongly agreed with the use of English songs in the classroom because songs have the power to change a boring classroom to a more cheerful and colourful lesson which in turn leads to greater motivation to learn the language. Setia et. al [12] also approved this finding as their study supports that using songs to teach English created positive feedbacks from the students compared to traditional method of relying on the textbook. It was demonstrated as shown in Table 4, where English songs promoted pupils' active participation in teaching and learning. In today's globalised world, our younger ESL learners need to be taught by using more interesting teaching approaches and styles.

The finding of this research revealed that both weak and intermediate pupils shown positive attitude toward the use of English songs in rural English classroom, therefore the first research question of this study had been answered. Chandler [3] supported this finding by stating that songs helped the children of an elementary level to have a positive attitude as songs made them feel more relaxed to learn. The weak and intermediate pupils of Kanowit were more motivated to study English integrated with English songs. This finding had answered the second research question of this study.

Based on the findings of this study, it can be recommended that a similar study on the use of English songs could be done to improve learners' motivation to learn the second language with a different research method. It might be good to have a pre-test and a post-test to examine students' actual performance instead of just a questionnaires. The results would be more thorough and specific if a mixed-method is used.

One way of presenting songs to second language learners in a consequential way is through incorporating some of the techniques to make the teaching and learning more meaningful and fun. According to Linse [13], there are a number of different ways that songs can be presented to children. Instead of integrated English songs in learning, it is much creative if action songs is being used. Apart from involving pupils' movement, this method can expose vocabulary skills too. Using English songs is indeed an resourceful approach to facilitate the young, low proficiency rural pupils in comprehending action words.

Lastly, there could be a study to investigate whether there is any relation between rural pupils' demography such as their gender, their age, and their ethnicity toward their motivation in English learning classroom. Moreover, the current study did not investigate the pupils' demography factors toward the use of English songs in English classroom.

In a nutshell, the findings of this research had supported the impression that young ESL learners respond positively to songs [8][9][14][15]. This research also supported the belief that English songs are very useful aids in helping rural pupils to learn English more effectively. A more controlled research and detailed analyses are required to further strengthen the discussed claims.

\section{REFERENCES}

[1] Jamali Ismail., and Hasliza Arif, "The need to speak English in Malaysia: what do learners say". In Trends in English language teaching. Selected papers from the Malaysia International Conference on English Teaching (MICELT) 1996 and 1998 (pp. 35-43). Serdang: University Putra Malaysia Press,2002.

[2] Thang, S.M., S.L. Ting and Nurjanah Mohd Jaafar, "Attitudes and Motivation of Malaysian Secondary Students Towards Learning English as a Second Language: A Case Study". The Southeast Asian Journal of English Language Studies, 2011, 17: 40-54.

[3] Chandler, C.M, "The relationship between music and language: Can teaching with songs result in improved second language learning",2016.

[4] Yunus M. M. et al, "Motivation and attitudes for learning English among year six students in primary rural school". Paper presented at WCES 2011.

[5] Gobel et al, "Attributions to Success and Failure in English Language Learning", 2013.

[6] Latchanna, Gara and Dagnew, Asrat( 2009). Attitude of Teachers Towards The Use of Active Learning Methods, Journal of All India Association of Educational Research, 2009, Vol. 21(1). Available: http://www.ejournal.aiaer.net/vol21109/12.\%20Latchana\%20\%26\%2 0 Dagnew.pdf

[7] Lennartsson, F. "Students' motivation and attitudes towards learning a second language:British and Swedish students' points of view", 2008.

[8] Schoepp, K. (2001). Reasons for using songs in the ESL/EFL classroom. The Internet TESL Journal, 7(2), 1-4. Available: http://iteslj.org/Articles/Schoepp-Songs.html

[9] Brewster, J., Ellis, G. \& D. Girard. The Primary English Teacher's Guide. Harmondsworth:Penguin, 2002.

[10] Schmitt, N., "Instructed second language vocabulary learning". Language Teaching Research, 12, 2008, 329-363.

[11] Nadera, B., "Promoting student motivation in EFL classroom: Through extended music education". Procedia-Social and Behavioral Sciences, 199, 2015, 368-371

[12] Setia, R., Rahim, R., Nair, G., Mohd Adam, A., Husin, R., Sabapathy, E., Mohamad, R., \& Mat So "e, S. (2012). English songs as means of aiding students' proficiency development. (Master's thesis, University MARA(UITM).Available: http://ccsenet.org/journal/index.php/ass/article/view/17633/11818

[13] Linse, T. C., "Practical English Language Teaching: Young Learners". New York: McGraw Hill, 2005.

[14] Lusi Nurhayati. "Using songs to promote fun English learning at elementary school". Paper presented at TEYLIN UMK, Indonesia. 2012.

[15] Thain, L. A., "Rhythm, music, and young learners: a winning combination". In A. M. Stoke (Ed.), JALT 2009 Conference Proceedings. Tokyo: JALT, 407-416.

Joyce Joel is a student of Master in Education at a Faculty of Education, National University of Malaysia, 43600 Bangi, Selangor, Malaysia; she obtained her Bachelor of Education from the Teacher Training Institute of Gaya Campus, Kota Kinabalu Sabah, Malaysia (2009-2014). Currently work as a primary school teacher in Kanowit, Sarawak, Malaysia. She had been awarded with bronze medal for the innovation in the !st Creative and Innovative Teaching and Learning of Language (CINTELL) at Universiti Malaysia Pahang, Malaysia.

Dr. Parilah Mohd Shah is an Associate Professor at a Faculty of Education, National University of Malaysia, 43600 Bangi, Selangor, Malaysia. She obtained her M.A. and Ph.D. from the University of Connecticut, USA. Her research inerests are second language acquisition, reading, teaching of English to speakers of other languages, and bilingual-bicultural education. She had presented several papers at both the national and international levels and has several publications in areas related to second language acquisition and learning. 